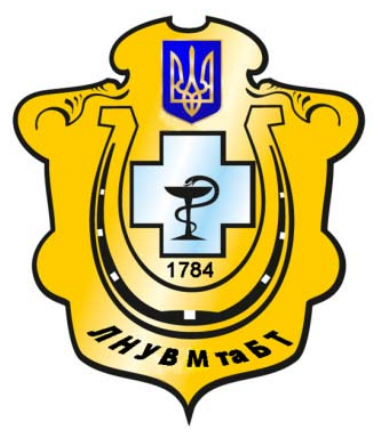

Науковий вісник Львівського національного університету ветеринарної медицини та біотехнологій імені С.3. Гжицького

Scientific Messenger of Lviv National University of Veterinary Medicine and Biotechnologies named after S.Z. Gzhytskyj

doi:10.15421/nvlvet7612

ISSN 2519-2701 print

ISSN 2518-1327 online

$\underline{\text { http://nvlvet.com.ua/ }}$

УДК $631.3: 681.3$

\title{
Автоматизована система обчислення раціонів годівлі сільськогосподарських тварин
}

\author{
Б.I. Козій, О.І. Степанюк \\ k_itm@ukr.net \\ Львівський національний університет ветеринарної медицини та біотехнологій імені С.3. Гжицького, \\ вул. Пекарська, 50, м. Львів, 79010, Україна
}

При обчисленні рачіонів годівлі сільськогосподарських тварин необхідно використовувати значну кількість довідкового матеріалу. Сюди відноситься інформачія про характеристики кормів та норми годівлі тварин. Пропонується зберігати ию інформацію у вигляді бази даних, яка утворена засобами табличного процесора MS Ехсеl. База даних міститься у кількох табличях. Структура бази даних передбачає наявність таких таблиць: табличя еталонної бази даних про корми; таблиия робочої бази даних; таблиия кормових добавок; таблиия бази даних про норми годівлі тварин; таблиия з інформаиісю про максимально допустимі норми вмісту кормів в раціоні тварин.

Таблиия еталонної бази даних є захищеною від випадкових змін і служить еталоном, з якого можна при потребі копіювати інформацію в таблищю робочої бази даних. Таблицю робочої бази даних можна актуалізувати, вносячи в неї для кожного корму зміни, що одержані в результаті лабораторних аналізів вмісту в кормі поживних речовин.

Система містить розрахункову таблищю, яка призначена для формування рачіону годівлі тварини певної статевовікової групи за запропонованим алгоритмом. Користувач має можливість задавати вміст у раціоні кожного виду корму, враховуючи його поживність, у відсотках від загальної поживності раціону. При иъьму попередньо в розрахункову таблицю за допомогою системи макросів вводиться інформація з таблиці бази даних про норми годівлі для даної тварини та інформачія про максимально допустимий вміст кожного з кормів в обчислюваному раціоні.

Ключові слова: електронна база даних, корми, норми годівлі тварин, свинарство, табличний процесор, математична модель, рачіони годівлі тварин.

\section{Автоматизированная система расчета рационов кормления сельскохозяйственных животных}

\author{
Б.И. Козий, О.И. Степанюк \\ k_itm@ukr.net
}

Львовский национальный университет ветеринарной медицины и биотехнологий имени С.3. Гжицкого, ул. Пекарская, 50, г. Львов, 79010, Украина

\begin{abstract}
При вычислении рачионов кормления сельскохозяйственных животных необходимо использовать значительное количество справочного материала. Сюда относится информация о характеристиках кормов и нормах кормления живорных. Предлагается сохранять эту информацию в виде базы данных, создаваемой средствами табличного процессора MS Exсеl. База данных содержится в нескольких табличах. Структура базы данных предусматривает наличие таких таблиц: таблииа эталонной базы данных о кормах; таблича рабочей базы данных; таблица кормовых добавок; таблица базы данных о нормах кормления животных; таблица с информацией о максимально допустимых нормах содержсания определенных кормов в рационе животных.

Таблица эталонной базы данных является защищенной от случайных изменений и служсит эталоном, с которого можна при потребности копировать информацию в таблииу рабочей базы данных. Таблииу рабочей базы данных можна акту-
\end{abstract}

\section{Citation:}

Kozij, B., Stepanjuk, O. (2017). Automated system calculation rations feeding farm animals. Scientific Messenger LNUVMBT named after S.Z. Gzhytskyj, 19(76), 61-66. 
ализировать, внося туда для каждого корма изменения, полученные в результате лабораторных анализов содержания в корме питательных вещчеств.

Система содержит расчетную таблицу, предназначенную для формирования рациона кормления животного определенной возрастной группь по предложенному алгоритму. Пользователь имеет возможность задавать содержание в рационе каждого вида корма, учитьввая его питательность, в процентах от общей питательности рациона. При этом предварительно в расчетную таблищу при помощчи системы макросов вводится информация с таблицы базы данных о нормах кормления для данного животного и информаџия о максимально допустимом содержании каждого из кормов в рассчитываемом рациине.

Ключевые слова: электронная база данных, корма, нормы кормления животных, свиноводство, табличный процессор, математическая модель, рационы кормления животных.

\title{
Automated system calculation rations feeding farm animals
}

\author{
B. Kozij, O. Stepanjuk \\ k_itm@ukr.net \\ Lviv National University of Veterinary Medicine and Biotechnologies named after S.Z. Gzhytskyi, \\ Pekarska Str., 50, Lviv, 79010, Ukraine
}

\begin{abstract}
When calculating feed rations of farm animals must use a considerable amount of reference material. This includes information about the characteristics of feed and animal feed regulations. It is proposed to keep this information in a database, which is formed by means of spreadsheet MS Excel. The database contained in several tables. The database structure provides for the following tables: Table reference database on feed; Table working database; Table feed additives; Table database on animal nutrition standards; a table listing the maximum permissible limits content of feed in the diet of animals. Table reference database is protected against accidental changes and serves as a benchmark from which to copy the information if necessary to table a working database. Working table can update the database, it makes a change for each feed that derived from laboratory analysis of content in the feed nutrients. The system includes the estimated table, which is intended to form the ration feeding the animals some sex-age groups of the proposed algorithm. The user can set content in the diet of each type of food as a percentage of the total dietary intake. This previously estimated in the table with the help of macros entered information from the database table rules of nutrition for the animal and information about the maximum content of each feed in the ration calculations.
\end{abstract}

Key words: electronic database, feed, animal feed standards, pigs, spreadsheet, mathematical model, animal feed rations.

Продуктивність тварин деякого стада, що характеризується певним генетичним потенціалом, залежить від впливу багатьох факторів зовнішнього середовища. Одним $з$ таких факторів є належна годівля високоякісними кормами при відповідній збалансованості добових раціонів тварин за усіма поживними речовинами (Cerenjk et al., 2015).

Процес обчислення раціонів годівлі тварин передбачає потребу в громіздкій роботі з великою кількістю довідкової інформації: табличними даними про вміст поживних речовин, макро- та мікроелементів, вітамінів у кожному виді корму, результатами лабораторних аналізів кормів, потребами в поживних речовинах тварин різних статево-вікових груп. Робота значно спрощується, якщо уся ця інформація зберігається в пам'яті комп'ютера у вигляді відповідної бази даних. При цьому виникає проблема розробки раціональної структури такої бази даних та наявності ефективної методики роботи з нею.

В даній роботі пропонується комп'ютерна система обчислення раціонів годівлі сільськогосподарських тварин, інформаційної основою якої служить база даних про характеристики кормів та норми годівлі тварин.

На нашу думку, доцільно створювати таку базу даних засобами табличного процесора, оскільки в подальшому буде зручно реалізувати алгоритм обчислення раціонів годівлі тварин та оптимізацію таких раціонів за допомогою електронних таблиць. Систему управління базою даних можна достатньо просто реалізувати за допомогою сукупності відповідних макросів (копіювання, доповнення, стирання).

База даних складається із сукупності реляційних таблиць. 3 нашого досвіду розробки обчислювальних інформаційних систем пропонується така структура бази даних.

1. Таблиця еталонної бази даних про корми, що можуть використовуватися для годівлі відповідного виду тварин. Для кожного корму в базі зберігається інформація про вміст в 1 кг поживних речовин, макро- та мікроелементів. Ця таблиця $є$ захищеною від випадкових змін і служить еталоном, з якого можна при потребі копіювати інформацію в таблицю робочої бази даних.

2. Таблиця робочої бази даних, яку можна актуалізувати, вносячи в неї для кожного корму відповідні зміни, що одержані в результаті лабораторних аналізів вмісту в кормі поживних речовин, оскільки при тривалому зберіганні кормів їхні властивості можуть змінюватися, а отже - не відповідати еталонним значенням. При роботі системи інформація з цієї таблиці використовується для автоматичного підрахунку вмісту в раціоні речовин, за якими балансується раціон.

3. Таблиця преміксів, яка містить інформацію про типи кормових добавок та їхні характеристики, що можуть використовуватися при годівлі даного виду тварин (Polistcuk and Bulavkina, 2010).

4. Таблиця бази даних про норми годівлі різних статево-вікових груп відповідного виду тварин. Кожний рядок таблиці відповідає одній з таких груп. Як- 
що в подальшому при роботі з системою виявиться, що користувач має потребу в обчисленні раціонів годівлі для інших груп тварин, він може доповнити базу, сформувавши відповідні нові рядки.

5. Таблиця з інформацією про максимально допустимі норми вмісту кормів в раціоні тварин.

У даній статті розглядається система обчислення раціонів годівлі свиней, а тому база даних містить відповідну інформацію.

На рис.1 зображено таблицю еталонної бази даних кормів, які можуть використовуватися при годівлі свиней. Таблиця містить довідкову інформацію про вміст поживних речовин, мікроелементів та вітамінів в 1 кг корму, яка є стандартною для даної території. Еталонна база даних кормів використовується для поновлення робочої бази, якщо виникає потреба. Таке поновлення реалізується шляхом копіювання вмісту таблиці еталонної бази в таблицю робочої бази даних кормів за допомогою макросу, який активізується кнопкою Копіювання бази (див. рис. 1) .

\begin{tabular}{|c|c|c|c|c|c|c|c|c|c|c|c|c|}
\hline & A & $\mathrm{B}$ & C & D & $\mathrm{E}$ & $\mathrm{F}$ & G & $\mathrm{H}$ & 1 & $\mathrm{~J}$ & K & L \\
\hline 1 & & \multicolumn{7}{|c|}{ База даних для обчислення раціону годівлі свиней } & \multirow{2}{*}{\multicolumn{3}{|c|}{ Копіювання бази }} & \\
\hline 2 & & & & Вміст пожи & ивних речо & Овин в 1 Кг & корму & & & & & \\
\hline 3 & Назва корму & Корм.од. & Об.енерг. & Суха реч. & Сир.прот. & Пер.прот. & Сир.клітк. & Лізин & Метіон.+цист. & Кальцій & Фосфор & Каротин \\
\hline 4 & & $\mathrm{K \Gamma}$ & МДж & $\Gamma$ & $r$ & $r$ & $r$ & $\Gamma$ & $\Gamma$ & $\Gamma$ & $\Gamma$ & MI \\
\hline 5 & Горох (екструд.) & 1,18 & 13,06 & 850 & 218 & 192 & 54 & 14,2 & 5,5 & 2 & 4,3 & 0,2 \\
\hline 6 & Oвec & 1 & 10,78 & 850 & 108 & 79 & 97 & 3,6 & 3,2 & 1,5 & 3,4 & 1,3 \\
\hline 7 & Пшениця & 1,28 & 13,56 & 850 & 133 & 106 & 17 & 3 & 3,7 & 0,8 & 3,6 & 1 \\
\hline 8 & Ячмінь & 1,15 & 12,7 & 850 & 113 & 85 & 49 & 4,1 & 3,6 & 2 & 3,9 & 0,3 \\
\hline 9 & Кукурудза & 1,33 & 13,67 & 850 & 103 & 73 & 38 & 2,1 & 3,3 & 0,5 & 5,2 & 3 \\
\hline 10 & Висівки пшен. & 0,75 & 9,28 & 850 & 151 & 97 & 88 & 5,4 & 3,9 & 2 & 9,6 & 2,6 \\
\hline 11 & Макуха соняшн. & 1,08 & 12,25 & 900 & 405 & 324 & 129 & 13,4 & 15,8 & 5,9 & 12,9 & 2 \\
\hline 12 & Шрот соняшн. & 1,03 & 12,54 & 900 & 429 & 386 & 144 & 14,2 & 16,7 & 3,6 & 12,2 & 3 \\
\hline 13 & Шрот сої $(48 \%)$ & 1,31 & 14,5 & 900 & 497 & 450 & 58 & 28,4 & 14,2 & 3,2 & 6,8 & 0,2 \\
\hline 14 & Шрот сої $(42 \%)$ & 1,21 & 14,2 & 900 & 420 & 380 & 64 & 27,1 & 12,3 & 3 & 6,4 & 0,2 \\
\hline 15 & Вика & 0,17 & 1,99 & 220 & 49 & 33 & 59 & 2,2 & 1,5 & 2,4 & 0,8 & 47 \\
\hline 16 & Конюшина & 0,2 & 2,13 & 235 & 39 & 27 & 61 & 1,5 & 0,7 & 3,7 & 0,6 & 40 \\
\hline 17 & Люпин & 0,19 & 2,25 & 200 & 43 & 31 & 57 & 1,9 & 1 & 1,9 & 0,5 & 27 \\
\hline 18 & Люцерна & 0,22 & 1,99 & 250 & 50 & 38 & 68 & 1,9 & 1,1 & 4,5 & 0,7 & 44 \\
\hline 19 & Картопля сира & 0,3 & 3,19 & 220 & 18 & 10 & 8 & 1 & 0,5 & 0,2 & 0,5 & 0,2 \\
\hline 20 & Картопля варена & 0,32 & 3,34 & 230 & 18 & 11 & 8 & 1 & 0,5 & 0,1 & 0,5 & 0 \\
\hline 21 & Буряк корм. & 0,12 & 1,74 & 120 & 13 & 9 & 9 & 0,4 & 0,2 & 0,4 & 0,5 & 0,1 \\
\hline 22 & Морква & 0,14 & 1,74 & 120 & 12 & 8 & 11 & 0,5 & 0,4 & 0,9 & 0,6 & 54 \\
\hline 23 & Жом свіжий & 0,12 & 1,74 & 112 & 12 & 6 & 33 & 1,2 & 0 & 1,5 & 0,14 & 0 \\
\hline 24 & Дріжджі сухі & 1,19 & 14,69 & 900 & 455 & 419 & 2 & 30,9 & 12,3 & 3,85 & 14,9 & 0 \\
\hline 25 & Молоко цільне & 0,3 & 2,88 & 130 & 35 & 33 & 0 & 2,8 & 1,2 & 1,3 & 1,2 & 0,9 \\
\hline 26 & Відвійки свіжі & 0,13 & 1,51 & 90 & 37 & 35 & 0 & 2,9 & 1,2 & 1,4 & 1 & 0 \\
\hline 27 & Сироватка свіжа & 0,13 & 1,1 & 59 & 10 & 9 & 0 & 0,6 & 0,1 & 0,4 & 0,5 & 0 \\
\hline 28 & Борошно М.-КістК. & 1,04 & 11,5 & 900 & 401 & 341 & 0 & 21,7 & 8,8 & 143 & 74 & 0 \\
\hline 29 & Борошно рибне & 0,98 & 13,34 & 900 & 621 & 571 & 0 & 49,7 & 26,1 & 66,6 & 36,2 & 0 \\
\hline 30 & Премікс & & & & & & & & & & & \\
\hline
\end{tabular}

\section{Рис. 1. Вигляд частини таблиці еталонної бази даних про вміст поживних речовин в кормах для свиней}

У цій таблиці в рядок 30 (рис. 1) при виконанні обчислень раціону годівлі для конкретної групи тварин слід вставити з таблиці преміксів інформацію про вміст поживних речовин, які містяться у вибраному преміксі.

Таблиця робочої бази даних кормів містить реальну інформацію про вміст поживних речовин, мікроелементів та вітамінів в 1 кг корму згідно з результатами лабораторних аналізів кормів. Реальна інформація вноситься в таблицю робочої бази даних після одержання результатів аналізів кормів.

У таблиці бази даних про норми годівлі міститься така інформація для різних статево-вікових груп відповідного виду тварин (рис. 2). Кожний рядок таблиці відповідає одній з таких груп. В нашому випадку це статево-вікові групи свиней різної живої маси, наприклад:

- норми годівлі поросят живою масою від 6 до 38 кг;

- норми годівлі свиней при середньодобовому прирості 550 г;

- норми годівлі свиней при середньодобовому прирості 800 г;

- норми годівлі холостих свиноматок;

- норми годівлі свиноматок в перші 84 дні супоросності та інші.

Якщо в подальшому при роботі з системою виявиться, що користувач має потребу в обчисленні раціонів годівлі для інших груп тварин, він може доповнити базу, сформувавши відповідні нові рядки. 


\begin{tabular}{|c|c|c|c|c|c|c|c|c|c|c|c|}
\hline & $\mathrm{A}$ & $\mathrm{B}$ & C & D & $E$ & $\mathrm{~F}$ & G & $\mathrm{H}$ & 1 & $\mathrm{~J}$ & $\mathrm{~K}$ \\
\hline 1 & \multirow{2}{*}{ Кнопка 1} & & & & & & & & & & \\
\hline 2 & & \multicolumn{3}{|c|}{ Норми годівлі поросят } & & & & & & & \\
\hline 3 & Жива маса ,кг & Корм.од. & Об.енерг. & Cyxa peч. & Сир.прот. & Пер.прот. & Сир.клітк. & Лізин & Метіон.+цист. & Кальцій & Фосфор \\
\hline 4 & 6 & 0,51 & 5,66 & 320 & 87 & 73 & 11 & 4,5 & 2,7 & 4,4 & 3,3 \\
\hline 5 & 8 & 0,6 & 6,66 & 410 & 103 & 84 & 15 & 5,1 & 3,1 & 4,7 & 3,7 \\
\hline 6 & 10 & 0,7 & 7,77 & 470 & 118 & 96 & 17 & 5,9 & 3,5 & 5,4 & 4,3 \\
\hline 7 & 12 & 0,8 & 8,88 & 540 & 135 & 111 & 19 & 6,8 & 4,1 & 6,2 & 4,9 \\
\hline 8 & 14 & 0,91 & 10,09 & 650 & 150 & 123 & 27 & 7,2 & 4,3 & 6,7 & 5,4 \\
\hline 9 & 16 & 1,03 & 11,43 & 740 & 171 & 140 & 31 & 8,2 & 4,9 & 7,7 & 6,1 \\
\hline 10 & 18 & 1,13 & 12,54 & 810 & 187 & 153 & 34 & 9 & 5,4 & 8,4 & 6,7 \\
\hline 11 & $20-28$ & 1,5 & 16,6 & 1150 & 230 & 179 & 60 & 10,4 & 6,2 & 11 & 9 \\
\hline 12 & $30-38$ & 1,8 & 20 & 1390 & 278 & 217 & 72 & 12,5 & 7,7 & 13 & 10 \\
\hline 22 & \multirow{2}{*}{ Кнопка 1} & & & & & & & & & & \\
\hline 23 & & \multicolumn{7}{|c|}{ Норми годівлі свиней при середньодобовому прирості 800 г } & & & \\
\hline 24 & Жива маса ,кг & Корм.од. & Об.енерг. & Cyха реч. & Сир.прот. & Пер.прот. & Сир.клітк. & Лізин & Метіон.+цист. & Кальцій & Фосфор \\
\hline 25 & 40 & 2,5 & 27,7 & 1950 & 339 & 263 & 109 & 14,2 & 8,5 & 16 & 14 \\
\hline 26 & 50 & 2,9 & 32,2 & 2270 & 395 & 306 & 127 & 16,6 & 10 & 19 & 16 \\
\hline 27 & 60 & 3,2 & 35,5 & 2500 & 435 & 338 & 140 & 18,3 & 11 & 21 & 17 \\
\hline 28 & 70 & 3,6 & 40 & 2690 & 448 & 350 & 160 & 18,4 & 11 & 22 & 18 \\
\hline 29 & 80 & 3,8 & 80 & 2840 & 463 & 361 & 182 & 18,5 & 11,1 & 23 & 19 \\
\hline 30 & 90 & 4,1 & 45,6 & 3060 & 499 & 389 & 196 & 19,9 & 11,9 & 25 & 20 \\
\hline 31 & $100-120$ & 4,4 & 48,9 & 3280 & 537 & 417 & 210 & 21,3 & 12,8 & 27 & 22 \\
\hline
\end{tabular}

Рис. 2. Вигляд частини таблиці бази даних про норми годівлі свиней

Інформація з цієї таблиці бази даних для відповідної групи тварин копіюється в розрахункову таблицю за допомогою відповідного макросу, який активізує кнопка 1 (див. рис. 2).

Для допомоги користувачеві при обчисленні раціону годівлі для відповідної групи тварин із заданою масою база даних містить таблицю, в якій наведено максимально допустимі норми вмісту різних видів корму в добовому раціоні свиней у відсотках від поживності раціону (рис. 3). Потрібний стовпчик таблиці можна копіювати в розрахункову таблицю за допомогою відповідного макросу, який активізує кнопка 2 (див. рис. 3).

\begin{tabular}{|c|c|c|c|c|c|c|c|c|c|c|c|c|c|c|c|c|c|}
\hline & A & $B$ & $\mathrm{C}$ & $\mathrm{D}$ & $E$ & $\mathrm{~F}$ & G & $\mathrm{H}$ & 1 & $\mathrm{~J}$ & $\mathrm{~K}$ & L & $\mathrm{M}$ & $\mathrm{N}$ & 0 & $\mathrm{P}$ & Q \\
\hline 1 & Кнопка 2 & & & & \multicolumn{12}{|c|}{$\begin{array}{l}\text { Максимально допустимі норми вмісту кормів у добовому раціоні свиней } \\
\text { (в \% від поживності раціону) }\end{array}$} & \\
\hline 2 & \multirow{2}{*}{ Назва корму } & \multicolumn{9}{|c|}{ Поросята } & \multicolumn{7}{|c|}{ Відгодівля } \\
\hline 3 & & 6 & 8 & 10 & 12 & 14 & 16 & 18 & $20-28$ & $30-38$ & 40 & 50 & 60 & 70 & 80 & 90 & 100 \\
\hline 4 & Горох (екструд.) & 0 & 0 & 5 & 5 & 5 & 10 & 10 & 10 & 10 & 15 & 15 & 15 & 15 & 15 & 15 & 15 \\
\hline 5 & Овес & 0 & 0 & 0 & 5 & 5 & 5 & 5 & 7 & 8 & 10 & 10 & 10 & 12 & 12 & 12 & 15 \\
\hline 6 & Пшениця & 50 & 50 & 50 & 50 & 50 & 50 & 50 & 30 & 30 & 30 & 30 & 30 & 30 & 30 & 30 & 30 \\
\hline 7 & Ячмінь & 30 & 30 & 30 & 30 & 30 & 30 & 30 & 40 & 40 & 50 & 60 & 70 & 70 & 70 & 70 & 70 \\
\hline 8 & Кукурудза & 35 & 35 & 35 & 40 & 40 & 40 & 40 & 40 & 40 & 55 & 55 & 55 & 55 & 55 & 55 & 55 \\
\hline 9 & Висівки пшен. & 0 & 0 & 0 & 0 & 0 & 0 & 0 & 10 & 10 & 15 & 16 & 18 & 20 & 20 & 20 & 20 \\
\hline 10 & Макуха соняшн. & 0 & 0 & 5 & 5 & 10 & 10 & 10 & 10 & 10 & 15 & 15 & 20 & 20 & 20 & 20 & 20 \\
\hline 11 & Шрот соняшн. & 0 & 0 & 5 & 5 & 10 & 10 & 10 & 10 & 10 & 15 & 15 & 20 & 20 & 20 & 20 & 20 \\
\hline 12 & Шрот сої $(48 \%)$ & 20 & 20 & 20 & 20 & 20 & 20 & 20 & 15 & 15 & 15 & 15 & 15 & 15 & 15 & 15 & 15 \\
\hline 13 & Шрот сої $(42 \%)$ & 20 & 20 & 20 & 20 & 20 & 20 & 20 & 15 & 15 & 15 & 15 & 15 & 15 & 15 & 15 & 15 \\
\hline
\end{tabular}

Рис. 3. Вигляд частини таблиці бази даних про максимально допустимі норми вмісту різних видів корму в добовому раціоні свиней

Як приклад, наведено розрахункову таблицю для обчислення раціону годівлі свиней масою 40 кг із запланованим добовим приростом маси 800 г. На рис. 4 зображено частину такої таблиці. Норми годівлі вибрано з таблиці бази даних про норми годівлі свиней (рис. 2). Ця інформація автоматично вставляється в розрахункову таблицю (рядок 30, табл. 4). У відповідний стовпчик розрахункової таблиці (стовпчик В, табл. 4) автоматично вставляється інформація про максимально допустимі норми вмісту різних видів корму в добовому раціоні такої тварини (рис. 3).

При обчисленні раціону годівлі слід задати для кожного виду корму вміст його в раціоні у відсотках від норми кормових одиниць поживності раціону (стовпчик С, рис. 4), користуючись рекомендаціями, 
які містяться у стовпчику В розрахункової таблиці (рис. 4). При цьому автоматично підраховується:

$x_{i}$ - вміст в (кілограмах) $i$-го корму в раціоні (стовпчик D) за формулою

$$
x_{i}=x_{i \%} \cdot a_{i k} /\left(100 \cdot b_{k}\right) ;
$$

$P_{i j}$ - вміст в раціоні $j$-ї поживної речовини, що створюється кількістю $x_{i} i$-го корму за формулою

$$
P_{i j}=a_{i j} \cdot x_{i} \text {; }
$$

де $x_{i} \%$ - вміст в раціоні $i$-го корму (у відсотках від норми кормових одиниць);

$b_{k}$ - норма кормових одиниць в раціоні;

$a_{i k}$ - вміст кормових одиниць в 1 кг $i$-го виду кормy;

$a_{i j}$ вміст $j$-ї поживної речовини (в тому числі макро- та мікроелементів і вітамінів) в 1кг $i$-го виду кормy;

Далі автоматично підраховуються:

- сумарна маса раціону (клітина D29)

$$
X=\sum_{i=1}^{N} x_{i}
$$
раціоні

сумарний вміст кожної поживної речовини в

$$
\left.A_{j}=\sum_{i=1}^{N} P_{i j} \quad \text { (для } \mathrm{j}=1,2, \ldots, \mathrm{M}\right),
$$

де $N$ - кількість використаних видів кормів; $M$ кількість видів поживних речовин, за якими здійснюється балансування раціону. Далі система обчислює відхилення вмісту $j$-ї поживної речовини від заданої норми

$$
\Delta A_{j}=A_{j}-b_{j} .
$$

Оскільки всі обчислення здійснюються практично миттєво після задання процентного вмісту $i$-го корму, то протягом короткого проміжку часу користувач

\begin{tabular}{|c|c|c|c|c|c|c|c|c|c|c|c|}
\hline & A & $\mathrm{B}$ & $\mathrm{C}$ & D & $E$ & $\mathrm{~F}$ & $\mathrm{G}$ & $\mathrm{H}$ & 1 & $\mathrm{~J}$ & K \\
\hline 1 & & & & & & \multicolumn{5}{|c|}{ Таблиця для виконання обчислень } & \\
\hline 2 & Назва корму & Макс.допуст. & Вміст & Вмміст & Корм.од. & Об.енерг. & Суха реч. & Сир.прот. & Пер.прот. & Сир.клітк. & Лізин \\
\hline 3 & & $\%$ & $\%$ к.о. & $\mathrm{Kr}$ & $\mathrm{K \Gamma}$ & МДж & $r$ & $r$ & \begin{tabular}{|r|}
$\Gamma$ \\
\end{tabular} & \begin{tabular}{r|r}
$r$ \\
\end{tabular} & $r$ \\
\hline 4 & Горох (екструд.) & 15 & 0 & 0,000 & 0,00 & 0,00 & 0,00 & 0,00 & 0,00 & 0,00 & 0,00 \\
\hline 5 & Oвec & 10 & 0 & 0,000 & 0,00 & 0,00 & 0,00 & 0,00 & 0,00 & 0,00 & 0,00 \\
\hline 6 & Пшениця & 30 & 30 & 0,586 & 0,75 & 7,95 & 498,05 & 77,93 & 62,11 & 9,96 & 1,76 \\
\hline 7 & Ячмінь & 50 & 38 & 0,826 & 0,95 & 10,49 & 702,17 & 93,35 & 70,22 & 40,48 & 3,39 \\
\hline 8 & Кукурудза & 55 & 0 & 0,000 & 0,00 & 0,00 & 0,00 & 0,00 & 0,00 & 0,00 & 0,00 \\
\hline 9 & Висівки пшен. & 15 & 1 & 0,033 & 0,03 & 0,31 & 28,33 & 5,03 & 3,23 & 2,93 & 0,18 \\
\hline 10 & Макуха соняшн. & 15 & 15 & 0,347 & 0,38 & 4,25 & 312,50 & 140,63 & 112,50 & 44,79 & 4,65 \\
\hline 11 & Шрот соняшн. & 15 & 0 & 0,000 & 0,00 & 0,00 & 0,00 & 0,00 & 0,00 & 0,00 & 0,00 \\
\hline 12 & Шрот сої $(48 \%)$ & 15 & 0 & 0,000 & 0,00 & 0,00 & 0,00 & 0,00 & 0,00 & 0,00 & 0,00 \\
\hline 13 & Шрот сої $(42 \%)$ & 15 & 0 & 0,000 & 0,00 & 0,00 & 0,00 & 0,00 & 0,00 & 0,00 & 0,00 \\
\hline 14 & Вика & 7 & 0 & 0,000 & 0,00 & 0,00 & 0,00 & 0,00 & 0,00 & 0,00 & 0,00 \\
\hline 15 & Конюшина & 8 & 0 & 0,000 & 0,00 & 0,00 & 0,00 & 0,00 & 0,00 & 0,00 & 0,00 \\
\hline 16 & Люпин & 7,5 & 0 & 0,000 & 0,00 & 0,00 & 0,00 & 0,00 & 0,00 & 0,00 & 0,00 \\
\hline 17 & Люцерна & 9 & 0 & 0,000 & 0,00 & 0,00 & 0,00 & 0,00 & 0,00 & 0,00 & 0,00 \\
\hline 18 & Картопля сира & 0 & 0 & 0,000 & 0,00 & 0,00 & 0,00 & 0,00 & 0,00 & 0,00 & 0,00 \\
\hline 19 & Картопля варена & 50 & 12 & 0,938 & 0,30 & 3,13 & 215,63 & 16,88 & 10,31 & 7,50 & 0,94 \\
\hline 20 & Буряк корм. & 2 & 0 & 0,000 & 0,00 & 0,00 & 0,00 & 0,00 & 0,00 & 0,00 & 0,00 \\
\hline 21 & Морква & 2,5 & 0 & 0,000 & 0,00 & 0,00 & 0,00 & 0,00 & 0,00 & 0,00 & 0,00 \\
\hline 22 & Жом свіжий & 2 & 0 & 0,000 & 0,00 & 0,00 & 0,00 & 0,00 & 0,00 & 0,00 & 0,00 \\
\hline 23 & Дріжджі сухі & 2 & 0 & 0,000 & 0,00 & 0,00 & 0,00 & 0,00 & 0,00 & 0,00 & 0,00 \\
\hline 24 & Молоко цільне & 0 & 0 & 0,000 & 0,00 & 0,00 & 0,00 & 0,00 & 0,00 & 0,00 & 0,00 \\
\hline 25 & Відвійки свіжі & 1,5 & 0 & 0,000 & 0,00 & 0,00 & 0,00 & 0,00 & 0,00 & 0,00 & 0,00 \\
\hline 26 & Сироватка свіжа & 3 & 0 & 0,000 & 0,00 & 0,00 & 0,00 & 0,00 & 0,00 & 0,00 & 0,00 \\
\hline 27 & Борошно М.-кістк. & 3 & 1 & 0,024 & 0,03 & 0,28 & 21,63 & 9,64 & 8,20 & 0,00 & 0,52 \\
\hline 28 & Борошно рибне & 3 & 3 & 0,077 & 0,08 & 1,02 & 68,88 & 47,53 & 43,70 & 0,00 & 3,80 \\
\hline 29 & Разом & & 100 & 2,83 & 2,50 & 27,43 & 1847,19 & 390,98 & 310,27 & 105,66 & 15,24 \\
\hline 30 & Норма & & & & 2,5 & 27,7 & 1950 & 339 & 263 & 109 & 14,2 \\
\hline
\end{tabular}
може знайти таке поєднання кормів в раціоні, при якому відхилення вмісту основних поживних речовин від норми не перевищує допустимих меж, одержати добре збалансований раціон.

Рис. 4. Вигляд частини розрахункової таблиці для обчислення раціону годівлі свиней масою 40 кг 3 добовим приростом маси 800 г

Наведену розрахункову таблицю також можна використати для оптимізації добового раціону годівлі тварин за його мінімальною собівартістю. Для цього робочу таблицю бази даних слід доповнити стовпчиком, який містить реальні ціни усі видів корму, та використати математичну модель оптимізації раціонів годівлі тварин (Kozij et al., 2001).

Таким чином, запропонована система дозволяє швидко здійснювати весь комплекс обчислень, які необхідно виконати для знаходження раціонів годівлі 
сільськогосподарських тварин. Система містить усю інформацію, яка використовується при обчисленні раціонів годівлі тварин у вигляді реляційної бази даних та алгоритм таких обчислень в середовищі табличного процесора.

Система $є$ відкритою, що дозволяє в подальшому наповнювати базу даних новою інформацією, а також надавати системі нових можливостей в напрямі розв'язування оптимізаційних задач.

\section{Бібліографічні посилання}

Kozij, B., Kravciv, R., Kyryliv, J., Pankiv, I. (2001). Rozrachunky u tvarynnyctvi zasobamy tablycsnoho procesora Excel. (in Ukrainian).

Polistcuk, A.A., Bulavkina, T.P. (2010). Sucsasni kormovi dobavky v hodivli tvaryn i ptyci. Visnyk Poltavskoi ahrarnoi akademij. 2, 63-66 (in Ukrainian).

Cerenjk, O.M., Akimov, O.V., Kosov, M.O. (2015). Povnocinna hodivla svynej. Sucsasne tvarynnyctvo. Sucsasne tvarynnyctvo. 6 (301). - Rezhym dostupu do resursu: http://www.agro-business.com.ua/suchasnetvarynnytstvo/2963povnotsinna-godivliasvynei.html. (in Ukrainian).

Стаття надійшла до редакиії 1.03.2017 